\title{
PENDANAAN TERORISME DI PEROLEH DARI TINDAK PIDANA PENCUCIAN UANG (MONEY LAUNDERING)
}

\author{
H. M. Abdi Koro*
}

\begin{abstract}
Countries in the world have been aware of and have made various efforts to fight, freeze, supervise, control the financing of terrorism, either through anti-terrorism law regime, or through anti-money laundering legal regime. These efforts are accompanied by acts of legislation, harmonization of national laws are adapted to the standards of international law, bilateral, regional and international. Indonesia as one of the countries of the world community and have become victims of terrorist acts has also proactively take part in these efforts. From the aspect of the legal regime against money laundering, the government has recorded significant progress well, in terms of legislation, regulation of financial institutions, as well as the institutional (institutions). Thus currently it is not easy for terrorists to use the network financial institution to finance the terrorist act in Indonesia. From the aspect of anti-terrorism law regime, particularly the financing of terrorism, the government of Indonesia noted some progress, particularly by ratifying, "International Convention For the Suppression of the Financing of Terrorism". With the ratification, the Indonesian government has a strong legal foundation in conducting legal measures to combat financing of terrorism with other countries.
\end{abstract}

Keywords: Combating terrorism and money laundering to the roots.

\begin{abstract}
Abtrak
Negara-negara di dunia telah menyadari dan telah melakukan berbagai upaya untuk melawan, membekukan, mengawasi, mengendalikan pendanaan terorisme, baik melalui undang-undang anti-terorisme, atau melalui undang-undang anti-pencucian uang. Upaya ini disertai dengan tindakan hukum, harmonisasi hukum nasional yang disesuaikan dengan standar hukum internasional, bilateral, regional dan
\end{abstract}

* Kepala Biro Pengawasan Hakim (2005-2010) dan Tenaga Ahli Komisi Yudisial RI; Ketua Widyaiswara Indonesia (IWI) se-Indonesia; Lektor Kepala Universitas Prof. Dr. Moestopo (Beragama) Jakarta dan dosen beberapa Perguruan Tinggi dan Pascasarjana di Jakarta dan Bandung. Alamatkontak: tikarinijedulz@gmail.com 
internasional. Indonesia sebagai salah satu negara masyarakat dunia dan telah menjadi korban tindakan teroris juga telah proaktif mengambil bagian dalam upaya ini. Dari aspek undang-undang terhadap pencucian uang, pemerintah telah mencatat kemajuan yang signifikan, dalam hal legislasi, regulasi lembaga keuangan, serta kelembagaan (institusi). Dengan demikian saat ini tidak mudah bagi teroris untuk menggunakan lembaga jaringan keuangan untuk membiayai aksi teroris di Indonesia. Dari aspek undang-undang anti-terorisme, khususnya pendanaan terorisme, pemerintah Indonesia mencatat beberapa kemajuan, terutama dengan meratifikasi, "Konvensi Internasional Untuk Pemberantasan Pendanaan Terorisme". Dengan ratifikasi, pemerintah Indonesia terorisme dengan negara lain memiliki landasan hukum yang kuat dalam melakukan tindakan hukum untuk memerangi pendanaan.

Kata kunci: pencucian uang, terorisme, ratifikasi

\section{Pendahuluan}

Terorisme bunuh diri (suicide terrorism) ${ }^{1}$ yang terjadi di Kuta dan Jimbaran pada tanggal 1 Oktober 2005 menambah panjang catatan serangan teroris di Indonesia. ${ }^{2}$ Apa yang terjadi di Indonesia, dialami pula oleh negara-negara lain.

${ }^{1}$ Terorisme bunuh diri (suicide terrorism) modern muncul pada awal tahun 1980-an dan berkembang menjadi suatu fenomena yang sudah lazim digunakan oleh para teroris. Perintis terorisme bunuh diri adalah kelompok teroris Hizbollah. Banyak kelompok terorisme lainnya mengikuti dan mengadopsi model terorisme bunuh diri ini, di antaranya kelompok teroris di Sri Lanka, Israel, Otoritas Palestina, Turkey dan Rusia. Al Qaeda, di bawah pimpinan Osama bin Laden, mentransformasikan terorisme dengan bom bunuh diri ini dari penggunaannya sebagai alat politik yang berguna dan efisien dalam konflik-konflik lokal kepada suatu fenomena internasional bersifat destruktif dan jauh lebih luas. Sekalipun terorisme bunuh diri bukan satu-sarunya model aksi teror bagi Al-Qaeda dan afiliasinya, tetapi kelompok terorist ini lebih suka menggunakan metode terorisme bunuh diri ini, baik secara operasional maupun secara simbolik. (Schweitzer, Yoram \& Goldstein Ferber, Sari, "Al-Qaeda and the Internationalization of Suicide Terrorism". Memorandum No.78 November 2005. Jaffee Center for Strategic Studies. Tel Aviv University). Sebagaimana diketahui bahwa rentetan peristiwa terorisme yang terjadi belakangan ini di Indonesia dilakukan oleh kelompok Jemaah Islamiyah yang merupakan jaringan Al-Qaeda di Asia Selatan. Karena itu metode yang digunakan adalah sama yakni bom bunuh diri.

${ }^{2}$ Sepanjang tahun 2000 - 2005 terjadi ledakan bom aksi terorisme, sebagai berikut: Tanggal 1 Agustus 2000 terjadi di kediaman Duta Besar Filipina, Jakarta. Bom meledak dari sebuah mobil yang diparkir di depan rumah Duta Besar Filipina, Menteng, Jakarta Pusat. Jatuh korban 2 orang 
Tragedi 11 September 2001 di Amerika Serikat, drama penyanderaan di Moscow tanggal 23 Oktober 2002, ledakan bom di Bogota tanggal 7 Pebruari 2003, aksi teror di Madrid tanggal 11 Maret 2004 dan di Beslan 1 September 2004 adalah beberapa contoh serangan teroris yang menelan begitu banyak korban jiwa manusia dan harta benda.

Serangan bom bunuh diri lainnya terjadi di tiga hotel di Amman pada tanggal 9 Nopember 2005 yang menelan korban setidak-tidaknya 57 orang meninggal dan 300 orang lainnya luka-luka. ${ }^{3}$ Berbagai serangan terorisme tersebut telah menyadarkan negara-negara dunia akan ancaman terorisme global dan bahwa negara manapun rawan terhadap serangan teroris, serta perlunya segera melakukan segala tindakan

meninggal dunia, dan 21 orang luka-luka, termasuk Duta Besar Filipina Leonides T. Caday. Pada tanggal 27 Agustus 2000 terjadi di Kedutaan Besar Malaysia, Jakarta. Dalam peristiwa itu granat meledak dalam kompleks kedutaan. Tidak ada korban jiwa. Pada tanggal 13 September 2000, ledakan bom mengguncang dan menghacurkan lantai parkir P2 Gedung Bursa Efek Jakarta. 10 orang tewas, 90 orang luka-luka, 104 mobil rusak berat, dan 57 mobil rusak ringan. Pada tanggal 24 Desember 2000, terjadi serangkaian ledakan bom pada malam Natal di beberapa gereja di sejumlah kota di Indonesia. Total korban yang meninggal 16 orang, 96 luka-luka, 37 mobil rusak. Tanggal 23 September 2001, ledakan bom terjadi di Restoran KFC, Makassar, yang mengakibatkan kaca, langitlangit dan neon sign KFC pecah. Tidak ada korban jiwa. Sebuah bom lainnya yang dipasang di Kantor MLC Life Cabang Makassar tidak meledak. Tanggal 6 Nopember 2001, bom rakitan meledak di halaman Australian International School (AIS), Pejaten, Jakarta. Tidak ada korban jiwa. Pada tanggal 1 Januari 2002 terjadi Bom Malam Tahun Baru. Granat manggis meledak di depan Rumah Makan Ayam Bulungan, Jakarta. Satu orang tewas dan seorang lainnya luka-luka. Di Palu, Sulawesi Tengah, terjadi empat ledakan bom di beberapa gereja. Tidak ada korban jiwa. Pada tanggal 12 Oktober 2002, tiga ledakan bom dahsyat mengguncang Kuta, Bali. 202 orang meninggal. Mayoritas warga negara Australia. 300 orang lainnya luka-luka. Saat bersamaan, di Manado, Sulawesi Utara, bom rakitan juga meledak di kantor Konjen Filipina. Tidak ada korban jiwa. Tanggal 5 Desember 2002, bom rakitan yang dibungkus wadah pelat baja meledak di Restoran McDonald's, Makassar. 3 orang tewas dan 11 orang luka-luka. Tanggal 3 Pebruari 2003, bom rakitan meledak di lobi Wisma Bhayangkari, Mabes Polri, Jakarta. Tidak ada korban jiwa. Tanggal 27 April 2003, sebuah bom meledak di area publik Terminal 2F, Bandar Udara Internasional Soekarno-Hatta, Cengkareng, Jakarta. Dua orang luka berat, dan delapan lainnya luka sedang dan ringan. Tanggal 5 Agustus 2003, bom menghancurkan sebagian Hotel JW Marriot, Jakarta. 11 orang meninggal dunia, dan 152 orang luka-luka. Tanggal 9 September 2004, bomkembali meledak di Kedubes Australia. Lima orang tewas, dan ratusan lainnya luka-luka. Beberapa gedung di sekitarnya seperti Menara Plaza 89, Menara Grasia dan Gedung BNI, mengalami kerusakan. Tanggal 5 Juli 2005, sebuah bom meledak di halaman rumah Ahli Dewan Pemutus Kebijakan Majelis Mujahidin Indonesia, Abu Jibril alias M. Iqbal, di Pamulang Barat. Tidak ada korban jiwa. Dan tanggal 1 Oktober 2005 di Jimbaran dan Kuta Bali. (KOMPAS. Sabtu. 8 Oktober 2005. hal. 36)

\footnotetext{
${ }^{3}$ Harian KOMPAS, 11 Nopember 2005, hal. 10.
} 
untuk mencegah dan melawan terorisme. Romli Atmasasmita ${ }^{4}$ menyatakan bahwa salah satu tindakan perusakan peradaban ialah kegiatan terorisme.

Berbagai upaya memerangi terorisme telah dilakukan oleh Pemerintah hidonesia. Pada tanggal 9 September 2005, Detasemen 88 POLRI berhasil melacak dan melakukan penggebrekan anggota kelompok teroris di Batu, Jawa Timur, yang menyebabkan tewasnya Dr. Azahari, buronan POLRI dalam sejumlah kasus peledakan bom di Indonesia. ${ }^{5}$

Keberhasilan POLRI tersebut tentu saja merupakan suatu prestasi dalam memerangi terorisme di Indonesia sebagaimana keberhasilannya dalam menangkap para pelaku terorisme lainnya. Sama pula dengan keberhasilan CIA beberapa waktu lalu dalam menangkap Hambali yang bergelar "Osama bin Laden of South Asia", kepala operasi Jamaah Islamiyah di Asia Selatan yang juga dituduh bertanggung jawab atas sejumlah kasus peledakan bom di Indonesia. ${ }^{6}$

Keberhasilan operasi-operasi penangkapan para pelaku terorisme tentu saja penting dan strategis dalam memerangi terorisme baik di tingkat nasional, regional, maupun internasional. Tetapi, sebagaimana dikatakan pakar terorisme Matthew Leavit $^{7}$, yang sangat penting dicermati adalah masalah pendanaan terorisme. Colin Powell, Sekretaris Negara Amerika Serikat, mengakui bahwa garis kehidupan (lifeline) para teroris adalah uang. Pasca serangan teroris di New York dan Washington tanggal 11 September 2001, menurut Lorreta Napoleoni, ${ }^{8}$ timbul kesadaran bahwa mesin perang terorisme (the engine of the armed struggle) bukanlah politik maupun ideologi, tetapi ekonomi. Hal senada diungkapkan oleh Senator AS, Evan Bayh, ${ }^{9}$ yang menyatakan; "in this new war against terrorism, on the most critical battles will take place not in a foreign land, but in the financial world, ..." Pernyataan Bayh ini

4 "Masalah Pengaturan Terorisme Dan Perspektif Indonesia", (Jakarta: BPHN, Departemen Kehakiman dan HAM R.I., 2002), hal. 8.

${ }^{5}$ Ibid., hal. 1.

${ }^{6}$ Brian Ross, CIA Nabs Top Al Qaeda Leader, Alleged Mastermind of SE Asia Operations, ABCNews.com, August 15, 2003.

${ }^{7}$ http://www/aijac.org.au/updates/Aug-03. 2004).

${ }^{8}$ Loretta Napoleoni, Money and Terrorism, Strategic Inside, Volume III, Issue 4 (April

\footnotetext{
${ }^{9}$ http://bayh.senate.gov/issues_terror_finance_oped.html
} 
didasarkan pada realitas bahwa uang/dana memegang peranan penting dan menentukan eksistensi terorisme. Adalah suatu realitas pula bahwa terorisme global telah memanfaatkan institusi-institusi finansial untuk melakukan pencucian uang (money laundering) dengan menggunakan metode pemindahan uang yang canggih melampaui batas negara untuk kepentingan pedanaan terorisme. Dari perspektif ini, maka pencucian uang dan pendanaan terorisme merupakan masalah global yang tidak hanya mengancani keamanan, tetapi juga menghambat stabilitas, transparansi, efisiensi sistem finansial yang pada akhirnya menghancurkan kesejahteraan ekonomi dan berbagai sendi kehidupan manusia.

\section{Terorisme dan Tindak Pidana Pencucian Uang}

\section{Pendanaan Terorisme}

Pendanaan terorisme (the financing of terrorism) menurut United Nations International Convention for the Suppression of the Financing of Terrorism 1999 adalah sebagai berikut:

Funds mean assets of every kind, whether tangible or intangible, movable or immovable, however acquired, and legal documents or instruments in any form, including electronic or digital, evidencing title to, or interest in, such assets, including, but not limited to, bank credits, travellers cheques, money orders, shares, securities, bonds, drafts, letter of credit.(Article 1 paragraph 1)

Artikel 1 paragraf 3 Konvensi tersebut menyatakan bahwa pengertian "Proceeds" yang adalah "any funds derived from or obtained, directly or indirectly, through the commission of an offence set forth in Article 2". berikut:

Kejahatan yang ditetapkan dalam Artikel 2 paragraf 1. adalah sebagai

Any person who commits an offence with the meaning of this Convention if that person by any means, directly or indirectly, unlawfully and willfully, provides or collects funds with the intention that they should be used or in the knowledge that they are to be used, in full or in part, in order to carry out:

(a). An act which constitutes an offence within the scope of and as defined in one of the treaties listed in the Annex; or 
(b). Any other act intended to cause death or serious bodily injury to a civilian, or to any other person not taking an active part in the hostilities in a situation of armed conflict, when the purpose of such act, by its nature or context, is to intimidate a population, or to compel a government or an international organization to do or to abstain from doing any act.

Artikel 2 paragraf 3 menyatakan:

For an act to constitute an offence set forth in paragraph 1, it shall not be necessary that the funds were actually used to carry out an offence referred to in paragraph 1, subparagraphs (a) or (b).

Artikel 2 paragraf 3 ini menentukan bahwa tindakan kejahatan yang ditetapkan dalam paragraf 1 di atas tidak harus perlu dana tersebut secara aktual digunakan untuk melakukan kejahatan tersebut. Artinya sekalipun dana tersebut tidak digunakan, tetap dianggap telah terjadi tindakan kejahatan sebagaimana dimaksud paragraf 1 , subparagraf (a) atau (b). Percobaan untuk melakukan tindakan kejahatan dimaksud paragraf 1, juga dianggap sebagai melakukan tindakan kejahatan dimaksud paragraf 1, sebagaimana ditentukan dalam Artikel 2 paragraf 4 yang berbunyi: "Any person also commits an offence if that person attempts to commit an offence as set forth in paragraph 1 of this Article." Dalam Artikel 2 paragraf 5 ditetapkan pula, sebagai berikut:

Any person also commits an offence in that person:

(a). Participates as an accomplice in an offence as set forth in paragraph 1 or 4 of this Article;

(b). Organizes or directs others to commit an offence as set forth in paragraph 1 or 4 of this Article;

(c). Contributes to the commission of one or more offences as set forth in paragraphs 1 or 4 of this Article by a group of persons acting with a common purpose. Such contribution shall be intentional and either:

(i). Be made with the aim of furthering the criminal activity or criminal purpose of the group, where such activity or purpose involves the commission of an offence as set forth in paragraph 1 of this Article; or

(ii). Be made in the knowledge of the intention of the group to commit an offence as set forth in paragraph 1 of this Article. 
Ketentuan-ketentuan tersebut menjelaskan bahwa pendanaan terorisme menurut Konvensi tersebut mencakup pengertian dana itu sendiri, batasan pelaku dan tindakan/perbuatan yang berkaitan pendanaan itu yang merupakan suatu kejahatan.

\section{Pencucian Uang}

Pengertian pencucian uang (money laundering), menurut Yenti Garnasih $^{10}$ dengan mengutip pendapat Hurt, secara umum dapat dirumuskan sebagai suatu proses yang dilakukan untuk merubah hasil kejahatan seperti dari korupsi, kejahatan narkotika, perjudian, penyelundupan, dan kejahatan serius lainnya, sehingga hasil kejahatan tersebut menjadi nampak seperti hasil dari kegiatan yang sah karena asal usulnya sudah disamarkan atau disembunyikan. Inti dari kejahatan ini, menurut Garnasih, adalah perbuatan yang dilakukan untuk menyamarkan atau menyembunyikan hasil kejahatan sehingga tidak tercium oleh aparat, dan hasil kejahatan tersebut dapat digunakan dengan aman, seakan berasal dari kegiatan yang sah.

Menurut Pasal 1 angka 1 Undang-Undang Nomor 25 Tahun 2003 tentang Tindak Pidana Pencucian Uang (UUTPPU), pengertian pencucian uang adalah perbuatan menempatkan, mentransfer, membayarkan, membelanjakan, menghibahkan, menitipkan, membawa ke luar negeri, menukarkan atau perbuatan lainnya atas Harta Kekayaan yang diketahuinya atau patut diduga merupakan hasil tindak pidana dengan maksud untuk menyembunyikan asalusul harta kekayaan sehingga seolah-olah menjadi harta kekayaan yang sah.

Dari pengertian ini tampak ciri dari kejahatan pencucian uang, yaitu bahwa kejahatan pencucian uang bukan kejahatan tunggal, tetapi kejahatan ganda. Pencucian uang merupakan kejahatan yang bersifat follow up crime atau kejahatan lanjutan atas hasil kejahatan utama (core crime). Penentuan kejahatan utama dalam pencucian uang pada umumnya disebut sebagai unlawful activity atau predicate offense, yaitu menentukan daftar kejahatan apa saja yang hasilnya diproses dalam pencucian uang. Selain itu dalam kejahatan pencucian uang terdapat dua kelompok pelaku yaitu kelompok yang berkaitan dengan langsung dengan kejahatan utama (core crime) yang disebut principle violeter dan kelompok kedua yang sama sekali tidak berkaitan langsung dengan kejahatan utama, misalnya pihak Penyedia Jasa Keuangan, baik

10 Yenti Garnasih, Kriminalisasi Pencucian Uang di Indonesia dan Permasalahan Implementasinya, Media Hukum Vol.2 No.10: 22 Mi 2004, hal. 28. 
lembaga perbankan maupun lembaga keuangan non bank. Kelompok kedua ini disebut sebagai aiders atau abettors. ${ }^{11}$

Dari pengertian di atas dalam kaitan dengan pendanaan terorisme, timbul pertanyaan: apakah dana yang diperoleh secara legal yang misalnya ditransfer lewat institusi finansial dengan maksud dipergunakan untuk terorisme merupakan pencucian uang sebagaimana dimaksud dalam rumusan pengertian di atas? Pasal 2 ayat (2) UUTPU menetapkan bahwa harta kekayaan yang dipergunakan secara langsung atau tidak langsung untuk kegiatan terorisme dipersamakan sebagai tindak pidana sebagaimana dimaksud pada Pasal 2 ayat (1) huruf n.

Elod Takats ${ }^{12}$ memberikan definisi yang lebih singkat, yakni: "money laundering is defined as an illicit money transfer". Pentransferan uang haram (hasil kejahatan). Menurut Takats ada dua jenis utama pentransferan uang haram. Pertama, pencucian uang tradisional sebagaimana dimaksud dalam pengertian pencucian uang tersebut di atas. Kedua, pendanaan terorisme (terrorism financing) yakni pentransferan dana-dana yang sebagian besar legal untuk tujuan yang ilegal (transferring mostly legal funds for illegal purposes). Tujuan yang ilegal dimaksud adalah untuk tindakan terorisme. Contohnya, hasil donasi karitatif yang legal yang ditransfer untuk mendanai aksi serangan teroris. Menurut Takats:

Both forms of money laundering are characterized by illicit and socially harmful fund transfers. Money laundering causes social harms because it facilitates crime and enable criminals to enjoy criminal revenues.

Dari perspektif pengertian pencucian uang yang dikemukakan Takats ini terletak hubungan antara kejahatan pencucian uang dalam pendanaan terorisme. Namun Penulis perlu menambahkan bahwa jenis kedua dari pentransferan uang haram, sebagaimana dikemukakan Takats di atas, tidak hanya mencakup pentransferan dana legal saja, tetapi juga dana-dana ilegal. Hal ini didasarkan pada realitas bahwa sumber pendanaan terorisme juga berasal dari hasil kejahatan seperti penyeludupan, perdagangan narkoba. Hal

${ }^{11}$ Ibid., hal. 33,

12 Elod Takats, A Theory of "Crying Wolf: The Economics of Money Laundering Enforcement", Job Market Paper, Princeton University, Department of Economics. November 9, 2005, hal. 5 . 
ini dapat dilihat dalam uraian mengenai sumber pendanaan terorisme berikut ini.

\section{Kejahatan Pencucian Uang dalam Pendanaan Terorisme}

\section{Sumber Pendanaan Terorisme}

Paul Dombroski ${ }^{13}$ mengatakan bahwa:

From the crudest of terrorist methods to the rapidly developing tactics of our present terrorist crises there has always been: one variable that has stayed constant - money. The one catalyst that plays the most important role in terrorism's existence is money.

Uang merupakan variable yang secara konstan selalu ada dalam sejarah terorisme dan memainkan peran yang sangat penting dalam eksistensi terorisme. Dombroski menjelaskan bahwa:

No terrorist or terrorist organization would be able to organize, recruit, plan, develop weapons, arm them, communicate or acquire intelligence, and carry out terrorist missions without funding. Since it is not possible for terrorists or terrorist organization to exist without money, they need a constant source. ${ }^{14}$

Seluruh kegiatan terorisme, mulai dari pengorganisasian, perencanaan, rekruitmen, keperluan dan pengembangan senjata, komunikasi, pengumpulan data intelijen, mobilisasi, sampai dengan tahap pelaksanaan aksi terorisme, tidak mungkin dilaksanakan tanpa dana. Untuk serangan 9/11 di New York dan Washington, sebagai contoh, diperkirakan oleh otoritas AS para teroris menghabiskan biaya antara US\$ 350.000,- hingga US\$ 500.000,-- ${ }^{15}$ Biaya Bom Madrid diperkirakan US\$15.000,-. Biaya untuk bom Bali I yang digunakan teroris diperkirakan sebesar US\$ 35.000,- Biaya untuk "The Bishopsgate bomb" di Kota London tahun 1993 diperkirakan sebesar £3.000,-Memang

13 Paul Dombroski. "The Methodology of Terrorism, Money Laundering and Financial Support of Terrorism".

${ }^{14}$ Ibid.

${ }^{15}$ The Economist, (http://www.economist.com/printedition) 
biaya ini tidak sebanding dengan kerugian yang ditimbulkan oleh aksi terorisme tersebut. Contohnya saja kerugian properti yang ditimbulkan oleh bom di Kota London tahun 1993 itu lebih dari £1 miliar. Belum korban yang mati dan luka-luka akibat ledakan tersebut.

Walaupun jumlah dana yang diperlukan itu relatif lebih kecil dibandingkan kerugian yang ditimbulkan tindakan kejahatan terorisme tersebut, tetapi intinya terorisme tidak dapat dilakukan, apalagi yang dapat menimbulkan akibat besar, tanpa dana. "Money is the life blood of terrorist operations." Kata Presiden AS, George W. Bush. ${ }^{16}$ Karena itu teroris memerlukan sumber-sumber dana yang tetap.

Al-Qaeda, menurut Rohan Gunaratna ${ }^{17}$, memiliki organisasi bisnis dan fmansial yang mengatur sumber-sumber dana yang diperlukan untuk kelangsungan organisasi teroris tersebut. Al-Qaeda tidak pernah beroperasi dalam keadaan terisolasi, karena sebagai organisasi teroris yang besar AlQaeda memerlukan dukungan dana teknik-logistik yang memang sudah ada beberapa tahun sebelumnya. Di Timur Tengah, khususnya di Teluk, A1-Qaeda memiliki dukungan publik, walaupun tersembunyi, dan mendapat bantuan dari kegiatan-kegiatan amal dan yayasan-yayasan, seperti UAE dan Arab Saudi. Di negara-negara berkembang strategi infiltrasi Al-Qaeda berhubungan dengan pemberian barang-barang dan jasa-jasa kepada kaum Muslim lokal, sedangkan di negara-negara demokrasi Eropa Al-Qaeda melakukan penggalangan dana untuk kaum Muslim yang memerlukannya di luar negara-negara Eropa. Pengumpulan dan penyaluran dana-dana tersebut memberikan peluang yang besar bagi pengembangan dukungan dan rekruitmen anggota organisasi terorisme tersebut.

Rohan Gunaratna, seperti dikutip Alex Schmid, ${ }^{18}$ mengidentifikasikan sumber-sumber utama pendanaan terorisme, sebagai berikut:

1. Sumber dana domestik yang berasal dan individu dan perusahaan baik yang merupakan sumbangan sukarela, maupun hasil pemerasan bersifat kursif (coercive extortion);

${ }^{16} \mathrm{Ibid}$.

${ }^{17}$ Rohan Gunaratna, "Inside Al-Qaeda, Global Network of Terror", (London, UK: C.Hurst \& Co. Ltd., August 2002), hal. 60-61.

${ }^{18}$ Alex,Schmid P., "Countering Terrorism through International Cooperation", (Milan: ISP AC, 2001), hal. 182-185. 
2. Sumber dana dan komunitas-komunitas migran yang menyebar, baik yang berupa sumbangan sukarela, maupun dan hasil pemerasan bersifat kursif;

3. Dukungan kelompok etnik dan kelompok agarna, berupa donasi dan kontribusi dari orang atau masyarakat dalam ikatan etnik dan agama;

4. Sokongan dana dari negara sponsor yang mendukung kelompok teroris untuk kepentingan negara bersangkutan atau melawan negara musuh;

5. Donatur pribadi dan publik dan penyongkong-penyokong dana individual untuk mendukung teroris dalam mengontrol kesejahteraan, organisasi sosial dan agama.

6. Hasil kejahatan, baik kejahatan biasa maupun dari kejahatan terorganisir (organized crime) berupa fraud, produksi ilegal, penyelundupan narkoba (drugs), pemalsuan dokumen, penculikan, perampokan bersenjata, pencucian uang, penyelundupan dan perdagangan manusia;

7. Hasil investasi dan bisnis yang legal di mana keuntungan dari investasi dan bisnis tersebut digunakan untuk mendanai terorisme;

8. Lembaga Swadaya Masyarakat (Non-governmental organizations) dan Organisasi Kemasyarakatan (community organizations) dibuat organisasi terorisme untuk mendapatkan dana dari "sister NGOs" di negara-negara lain atau menginfiltrasi organisasi-organisasi masyarakat yang ada, yang mendapatkan dana (grants).

Jika dilihat pendanaan Al Qaeda, organisasi terorisme yang diklaim bertanggung jawab atas aksi terorisme di dunia belakang ini, menurut keterangan Council on Foreign Relations, US, bekerja sama dengan Markle Foundation, ${ }^{19}$ sumber pendanaannya berasal dari: pertama, kekayaan Osama bin Laden sendiri, termasuk harta warisan senilai US\$ 30 juta. Perkiraan kekayaan bin Laden saat ini meningkat hingga US\$ 300 juta. Tetapi menurut beberapa mantan pejabat A.S. angka ini digelembungkan. Kedua, dana A1Qaeda berasal dari kaum Muslim kaya yang bersimpati dengan perjuangan Osama bin Laden. Mereka adalah orang-orang yang dulu memberikan dukungan dana kepada bin Laden pada tahun 1980-an ketika menghadapi Soviet di Afganistan. Para penyokong dana ini memiliki berbagai perusahaan, aset-aset yang besar dalam pusat-pusat finansial global, dan menggunakan teknik canggih untuk mengamuflase pentransferan dana ke Al-Qaeda. Ketiga,

\footnotetext{
${ }^{19}$ Council on Foreign Relations in cooperation with the Markle Foundation, Terroism: $Q \& A$, The Money: Drying Up the Funds for Terror (http://cfren-orism.org/response/money)
} 
A1-Qaeda mendapat dana dari hasil pemerasan (extortion) orang-orang kaya Saudi dan kaum Muslim di negara-negara lain yang kadang-kadang dilakukan di bawah ancaman terhadap bisnis atau pribadi. Keempat, dana-dana yang berasal dari hasil aktivitas ilegal yang dilakukan Al-Qaeda atau atas nama kelompok teroris tersebut, termasuk penyulundupan, perdagangan narkoba, perdangangan batu permata, emas yang ilegal. Kelima, berbagai macam bisnis dan organisasi-organisasi lainnya untuk menggelapkan hasil-hasil aktivitas ekonomi lainnya. Perdagangan madu Yemen, misalnya, digunakan sekaligus untuk dua tujuan yakni mendanai teroris dan menutupi penyelundupan narkoba (drugs), dan operasi Al-Qaeda. Keenam, kegiatan arnal sosial untuk mengumpulkan dana dan menutupi donasi-donasi yang diberikan kepada para teroris.

Menurut kesaksian Ronald K. Noble, Sekretaris Jenderal Interpol, di hadapan the United States House Committee on International Relations One Hundred Eight Congress, pada tanggal 16 Juli 2003, ${ }^{20}$ secara umum Al-Qaeda dan grup-grup afiliasinya mendapatkan dana sumbangan dari para simpatisan. Hal ini bisa mencakup dana-dana yang berasal dari aktivitas-aktivitas yang halal maupun yang haram. Satu perkiraan, selama lebih dari sepuluh tahun AlQaeda menerima antara US\$ 300 juta hingga US\$ 500 juta, rata-rata US\$ 30 hingga US\$ 50 juta setahun. Rata-rata 10\% dari dana tersebut digunakan untuk kepentingan operasi teroris, sementara 90\% digunakan untuk mempertahankan infrastruktur jaringan kerja (network), mencakup pemberian dana kepada grupgrup yang mendukung Al-Qaeda atau meningkatkan pengaruh Al-Qaeda di wilayahnya masing-masing, penyediaan fasilitas-fasilitas, organisasi dan komunikasi.

Penggunaan lain dari dana ini adalah untuk membayar jaminan perlindungan (the protection guarantee) Al-Qaeda di Afganistan dan Sudan.

Dalam kesaksian tertulis Jean-Charles Brisard ${ }^{21}$ di depan the Committee of Banking, Housing and Urban Affairs, United States Senate, pada tanggal 22

${ }^{20}$ Ronald Noble K., The link between intellectual property crime and terrorist financing", Text of public testimony, @Interpol, 14 November 2005 (http://www.interpol.mt/Public/ICPO/ Speeches/)

21 Jean-Charles Brisard adalah seorang pakar internasional dalam bidang pendanaan terorisme yang mulai melakukan investigasi jaringan pendanaan terorisme pada tahun 1997 untuk Pemerintah Perancis. Lalu untuk pemerintahan Negara-negara lain dan PBB. Sejak bulan Juni 2002, Brisard memimpin investigasi bagi "The 9/11 Family United to Bankrupt Terrorism" untuk kepentingan pengajuan tuntutan oleh 5.600 anggota keluarga korban di depan Pengadilan Distrik 
Oktober 2003, diungkapkan mengenai perkiraan David Aufhauser, US Treasury Department General Counsel, tentang anggaran tahunan Al-Qaeda yang mencapai US\$ 35 juta sebelum peristiwa 9/11. Angka ini diyakini Aufhauser pada saat ini berkisar antara US\$ 5 juta hingga US\$ 10 juta per tahun. Brisard sendiri pada bulan Desember 2002, dalam laporannya kepada Dewan Keamaan PBB, menilai pendapatan tahunan Al-Qaeda sebesar US\$ 50 juta dan aset globalnya dalam periode sepuluh tahun berkisar US\$ 300 juta hingga US\$ 500 juta. Sebelumnya, pada bulan Agustus 2002, Grup Monitoring Al-Qaeda PBB memperkirakan pendapatan tahunan Al-Qaeda sebesar US\$ 16 juta. Menurut suatu laporan intelijen, sebagaimana dikutip Brisard, pada tahun 2002 Saudi Arabia sendiri memberikan dana sebesar US\$ 1 juta hingga US\$ 2 juta per bulan melalui metode penggalangan dana untuk mesjid dan Iain-lain.

Dalam kesaksian Brisard tersebut juga diungkapkan bahwa Al-Qaeda secara jelas dalam panduan pelatihan militer (military training manual) ${ }^{22}$ dan dukomen-dokumen lainnya membedakan antara dana-dana organisasional (organizational funds) dengan dana-dana operasional (operational funds). Dana operasional memiliki dua tujuan utama, yakni; pertama, untuk investasi dalam proyek-proyek yang memberikan keuntungan finansial untuk menjaga kelangsungan dan mendukungan jaringan lokalnya (local cells), dan kedua, untuk melaksanakan operasi-operasi terorisme.

Terpisah dari tingkat operasional, terdapat juga dana-dana yang khusus digunakan untuk level kepentingan logistik harian dan "the super-structure lever. Hal ini merupakan inovasi terorisme yang diintrodusir oleh Osama bin Laden. Pada level kepentingan logistik harian adalah dana yang tujuannya menjaga jaringan organisasi di negara lain, mendanai mereka untuk

Washington, D.C. Amerika Serikat melawan beberapa badan, bank, perusahaan, dan individu yang memberikan dukungan finansial dan logistik kepada jaringan Al-Qaeda.

${ }^{22}$ Dalam buku manual yang berjudul "Declaration of Jihad Against the Country's Tyrants", seperti dikutip Gunaratna, Al Qaeda memerintahkan para kadernya untuk menghasilkan dan menggunakan uang-uang dan dokumen palsu, termasuk pemalsuan kartu kredit yang merupakan spesialisasi dari Al Qaeda Aljazair di Eropa. Kelompok teroris ini mengikuti lima prinsip keamanan finansial (Five Financial Security Principles):

Funds should be divided between those invested for financial return and the balance operational funds - that should be saved and spent only on operations; operational funds should not all be put in one place; only a few of the organization's members should know the location of its funds; while carrying large amounts of money precautions should be taken; and money should be left with non-members and spent only when needed. (lihat Gunaratna, Op. Cit., hal. 62). 
menstabilisasikan dan meningkatkan dukungan serta mengembangkan daya jangkauan. Selama bertahun-tahun Al-Qaeda secara finansial mendukung badan-badan, mulai dari Libya hingga Filipina, dari Indonesia hingga Somalia, dengan besaran angka berkisar jutaan dolar AS. Pada level "super-structure" dana-dana digunakan oleh Al-Qaeda untuk membayar perlindungan (protection) dan suaka (assylum) ${ }^{23}$. Sejak tahun 1991, Al-Qaeda harus berpindah-pindah dari satu negara ke negara lain, yakni Sudan dan Afganistan.

Menurut kesaksian tertulis Bisard, dana-dana tersebut terutama berasal dari para donatur kaya di Timur Tengah. Berdasarkan hasil investigasi untuk para keluarga korban tragedi 9/11, dan sebagai bagian dari suatu proses kerjasama yudisial dengan Negara Bosnia Herzegovina, Bisard menemukan bukti utama yang dapat membuktikan faktor ini. Daftar yang disebut "the Golden Chain list" dari para sponsor Saudi yang kaya merupakan suatu dokumen internal AlQaeda yang berhasil disita polisi Bosnia dari kantor-kantor Yayasan Internasional Benevolence (Benevolence International Foundation) di Sarajevo pada bulan Maret 2002. Tim investigasi Bisard diberikan akses pada dokumen ini, menyusul perintah dari Mankamah Agung Bosnia Herzegovina yang memerintahkan Pemerintah AS melepaskan dokumen ini. Dalam dokumen tersebut tercatat daftar-daftar "the Golden Chain" yang terdiri dari 20 orang Saudi Arabia yang memberikan sponsor finansial bagi Al-Qaeda, yang terdiri dari: 6 orang bankir, 12 orang pebisnis, dan 2 orang mantan menteri. Menurut perkiraan tim Bisard, besar dana kumulatif dari para sponsor ini lebih dari US\$ 85 miliar, atau 42\% dari GNP (Gross National Product) tahunan Arab Saudi dan sama dengan GNP Venezuela. Tercatat dalam daftar tersebut nama-nama seperti bankir terkenal Khalid Bin Mahfouz, businessman Saleh Abdullah Kamel, Keluarga Bin Laden, dan beberapa bankir yang mewakili tiga bank terbesar Saudi Arabia (National Commercial Bank, Riyadh Bank dan Al Rajhi Bank).

${ }^{23}$ Menurut Gunaratma, berdasarkan laporan intelijen AS, untuk membeli loyalitas Al Qaeda memberikan dana kepada individu-individu dari berbagai kelompok-kelompok Islam, termasuk Taliban. Dengan uang tersebut mereka memiliki pengaruh yang besar atas para pimpinan politik, agama, militer, menteri pertahanan, dan otonomi operasi dalam negri. Untuk menjamin keamanan dan kelancaran mobilitas barang dan para anggota, Al Qaeda juga membayar pegawai bea dan cukai, polisi dan tentara. Pada saat Afganistan berada di bawah rejim Taliban, Al Qaeda merupakan salah satu contoh "a state within a state". Secara tradisional, negara mensponsori dan mengontrol terorisme. Sebelum Oktober 2001, Al Qaeda menjadi kelompok teroris pertama di dunia yang mengontrol negara - the Islamic Emirate of Afghanistan. Lihat Gunaratma, Op.Cit. hal. 63. 
Hal ini membenarkan pendapat Seyyed Nasr, sebagaimana dikutip Paul Todd \& Jonathan Bloch, ${ }^{24}$ yakni:

... Saudi Arabia is the single most important cause and supporter of radicalisation, ideoligisation, and general fanaticism of Islam... if the United States wants to do something about radical Islam, it has to deal with Saudi Arabia.

Hal senada diungkapkan oleh Shelley Berkley, ${ }^{25}$ dengan mengutip kesaksian the general counsel for the Treasury Department di hadapan Senat AS pada tahun 2003, yang mendeskripsikan "Saudi Arabia as the epicenter of the world's terrorist money triar. Berkley juga mengutip Duta Besar Dore Gold, President of the Jerusalem Center for Public Affairs dan mantan Duta Besar Israel untuk PBB, yang melaporkan bahwa Hamas menerima US\$ 12 juta hingga US\$ 14 juta setiap tahun dari sumber-sumber di Saudi Arabia. ${ }^{26}$

Kenyataan-kenyataan tersebut menunjukkan bahwa sumber pendanaan terorisme terbesar, khususnya Al-Qaeda, di samping Hamas di Palestina, berasal dari sumber-sumber di Arab Saudi yang dilakukan lewat zakat dan kegiatan amal.

Di samping sumber pendanaan tersebut di atas, berdasarkan laporan BBC Monitoring Report (11/92002) dengan tajuk "Al-Qaeda Trading in Fake Branded Goods", Australian Financial Review (29/01/2003) bertajuk "Big Business Targets Terrorist Pirates", dilaporkan bahwa Al-Qaeda diduga terlibat dalam perdagangan barang-barang palsu. Investigasi terhadap suatu pengiriman barang-barang palsu dari Dubai ke Copenhagen, Denmark, menimbulkan

${ }^{24}$ Paul Todd, \& Jonathan Bloch, "Global Intelligence - The World's Secret Services Today", (London: Zed Books Ltd., 2003), hal. 14.

${ }^{25}$ Committee on International Relations, Saudi Arabia and The Fight Against Terrorism Financing", Hearing before the Subcommittee on the Middle East and Central Asia of the Committee on International Relations House of Representatives One Hundred Eight Congress, Second Session, Serial No. 108-109, March 24, 2004 (http:www.house.gov/international-relations), hal. 6.

26 Berkley mengungkapkan juga bahwa pada tahun 2001, Menteri Pertahanan Israel menemukan catatan-catatan dari Otoritas Palestina mengenai pendanaan terorisme oleh Saudi Arabia. Catalan tersebut memperlihatkan suatu kegiatan amal (charity) yang dikontrol oleh Menteri Luar Negeri Saudi mentrasfer dana sebesar \$55 juta kepada orang-orang Palestina. Sebesar \$545,000 dari dana tersebut dibagikan kepada 102 keluarga martis Palestina, termasuk delapan orang yang melakukan bom bunuh diri. (Ibid.) 
dikembangkan pada akhir tahun 1980-an, ketika penegakan hukum menghadapi perkembangan ancaman kartel-kartel narkoba Kolumbia, khususnya Kartel Cali dan Medellin. Kedua organisasi kejahatan ini mengakumulasi kekayaan dan kekuasaan yang begitu besar yang tidak lagi hanya menjadi persoalan keselamatan publik, tetapi telah menyangkut ancaman terhadap Negara itu sendiri. ${ }^{32}$

Strategi anti-pencucian uang ini digunakan pada saat itu untuk mengatasi masalah keterbatasan sarana-sarana tradisional dalam memerangi organisasi kejahatan. Satu-satunya kelemahan organisasi-organisasi kejahatan pada saat itu adalah kebutuhan mereka dalam menggunakan saluran-saluran institusi sistem finansial dan bank yang sah untuk mentransfer dana-dana hasil kejahatan dan menghilangkan jejak kejahatan asli yang telah menghasilkan dana-dana tersebut. Hal ini memudahkan proses pelacakan dengan tingkat kesulitan dan biaya yang relatif lebih murah, serta efektif untuk memerangi organisasi kejahatan.

Pasca tragedi 9/11 yang diikuti dengan pernyataan perang terhadap terorisme menunjukkan bahwa rasio dari strategi anti-pencucian uang tersebut di atas dapat digunakan secara mutatis mutandis dalam memerangi kelompokkelompok terorisme. ${ }^{33}$ Menurut Peter Alldridge ${ }^{34}$ tragedi 9/11 memberikan daya dorong perubahan yang lebih jauh dari fokus pengawasan pencucian uang dengan mempertimbangkan sarana-sarana pendanaan terorisme. "The expression 'laundering' was continually applied to the means by -which terrorist organisasitons were financed."

Berdasarkan pendapat Alldridge dan Takats dikaitkan dengan sumber dan tujuan pendanaan terorisme sebagaimana diuraikan di atas, maka jelas pendanaan terorisme dilakukan melalui mekanisme kejahatan pencucian uang.

Kejahatan pencucian uang yang dilakukan oleh Al Qaeda berkaitan erat dengan jaringan finansial (financial network) kelompok teroris tersebut.

32 Jean-Francois Thony, Money Laundering and Terrorism Financing, a paper originally delivered on May 10, 2000, when Thony served as a Judge in the Court of Appeals, Versailles, France.

${ }^{33} \mathrm{Ibid}$.

${ }^{34}$ Peter Alldridge, "Money Laundering Law: Forfeiture, Confiscation, Civil Recovery, Criminal Laundering and Taxation of the Proceeds of Crime", (Oxford, Portland: Hart Publishing, 2003), hal. 25. 
Jaringan flnansial Al Qaeda telah berkembang menjadi global dan canggih. Menurut Gunaratna ${ }^{35}$ :

Intelligence and security services worldwide, including the CIA and Ml 6, have never before encountered a global terrorist financial network as sophisticated as Al Qaeda's. Comparisons with other such networks reveal that Al Qaeda has built the most complex, robust and resilient money-generating and money-moving network yet seen.

Jaringan finansial Al Qaeda didukung oleh para anggota kelompok profesional yang terdiri dari para bankir, akuntan, pengelola finansial yang mengelola keuangannya di empat benua ${ }^{36}$. Untuk memindahkan dana-dana secara rahasia dari satu sumber ke pihak penerima, jaringan finansial Al Qaeda selalu menyamarkan identitas para pihak. Untuk tujuan ini Al Qaeda mendirikan institusi-institusi yang sah seperti bank, perusahaan, dan lembaga karitatif penggalang dana baik bersifat swasta maupun di bawah otoritas negara. Dalam hal ini, modus operandi Al Qaeda cocok dengan kelompok teroris lainnya, seperti Tamil Tigers dan Hamas. ${ }^{37}$

Dalam melakukan kejahatan pencucian uang Al-Qaeda menggunakan tiga jalur esensial dari jaringan finansialnya, yakni; pertama, sistem perbankan Islam (the Islamic Banking system), kegiatan bisnis (business transactions), dan kegiatan organisasi-organisasi karitatif (charities).

\section{Pendanaan Terorisme Di Indonesia}

Pada bulan Nopember tahun 2005 media massa melansir berita mengenai pendanaan kelompok terorisme Azahari dan Noordin M. Top yang dituduh

\footnotetext{
${ }^{35}$ Gunaratna, Op.Cit., hal. 61.
}

${ }^{36}$ Contohnya, Muhammad Jamal Khalifa, adalah orang yang dipercayakan untuk mengelola investasi di Mauritius, Singapura, Malaysia, dan Filipina. Yazid Suffat, pebisnis Malaysia tamatan sekolah di Amerika, yang merupakan terlibat pendanaan serangan 9/11. Pada tingkat global, pengelolaan dana Al Qaeda ditangani oleh pebisnis asal Arab Saudi di Ethiopia, Sheikh Muhammad Hussein al-Almadi. Di Afganistan - dan Peshawar- berbasis di Palestina, dikelola oleh Zein-alAbideen alias Abu Zubaydah. Di Karachi, dikelola oleh Mustafa Ahmed al-Hawsawi alias Mustafa Ahmed, yang mengkoordinasikan pendanaan operasi 9/11. Lihat Gunaratna, Op. Cit., hal. 65.

${ }^{37}$ Ibid., hal. 61. 
bertanggung jawab atas sejumlah aksi bom di Indonesia selama ini. Pengamat intelijen Wawan H. Purwanto, sebagaimana dimuat Harian Media Indonesia ${ }^{38}$, mengungkapkan seorang diplomat asing menjadi penghubung dan berperan mengalirkan dana untuk kegiatan teroris kelompok Azahari dan Noordin M. Top di Indonesia. Diplomat ini, demikian Purwanto, memiliki kekebalan internasional sehingga leluasa menyalurkan dana kepada kelompok teroris. Indikasi ini sudah diberitahukan Purwanto kepada DPR dan Pemerintah supaya diselidiki lebih jauh.

Di samping diplomat itu, menurut keterangan Purwanto yang dimuat Harian tersebut, aliran dana juga disalurkan melalui seorang kurir asal Malaysia dengan inisial Suf. Dana tersebut berasal dari sumbangan simpatisan yang sepaham dengan Azahari dan Noordin M. Top. Informasi ini diperoleh Purwanto dari Polisi Diraja Malaysia. Awalnya dana tersebut disalurkan Suf ke Indonesia melalui bank. Menurut Purwanto, pada tahun 2002-2003 disalurkan lewat satu bank asing di Indonesia, tanpa menyebutkan nama bank tersebut. Sedangkan di Malaysia, disalurkan lewat bank Pemerintah setempat. Setelah penyaluran lewat institusi bank ini terlacak, Suf mengubah cara pentransferan dana, yakni secara tunai lewat perorangan dengan sistem cut out, dipakai sekali saja kemudian jasa orang yang dipakai untuk mengalirkan dana tersebut diputuskan. ${ }^{39}$

Atas dugaan keterlibatan diplomat asing dalam pendanaan terorisme di Indonesia, Muladi, Gubernur Lembaga Ketahanan Nasional, berpendapat agar Pemerintah Indonesia jangan ragu menyelidiki dugaan tersebut. Terorisme bukan hanya merupakan urusan negara dengan negara, tetapi merupakan kerja sama internasional yang dikendalikan PBB, melalui Dewan Keamanan PBB. Tidak ada kekebalan ekstradisi bagi diplomat yang terlibat terorisme, sebab terorisme merupakan extraordinary crime? ${ }^{40}$

Dugaan keterlibatan diplomat asing dalam pendanaan terorisme di Indonesia ini dibantah oleh Sutanto, Kepala Kepolisian Negara Republik Indonesia. Menurut Sutanto, tidak ada diplomat asing yang ikut mendanai terorisme. Tetapi Sutanto mengakui adanya jaringan internasional yang ikut

${ }^{38}$ Aliran Dana dari Diplomat, Media Indonesia, 15 Nopember 2005.

${ }^{39}$ Ibid.

40 Media Indonesia online, Rabu 23 Nopember 2005 (http://www.mediaindonesia.com/newsprint.) 
mendanai aksi peledakan bom di Indonesia. Aliran dana antar negara menjadi salah satu sumber dana bagi kegiatan terorisme, termasuk Indonesia. ${ }^{41}$ Sutanto menyebutkan bahwa salah satu sumber dana beberapa peledakan bom di Indonesia berasal dari Arab Saudi. Pada tahun 2004 polisi telah menangkap seorang tersangka yang menerima dana dari Arab Saudi. Setelah penangkapan tersebut hubungan Arab Saudi dengan teroris di Indonesia terputus. ${ }^{42}$ Tersangka tersebut, menurut keterangan Sutanto, adalah seorang tenaga kerja Indonesia berinisial ALS yang terlibat pengiriman dana dari Arab Saudi ke Filipina. Namun hingga saat ini jaringan pendanaan yang melibatkan ALS itu belum terungkap dan untuk itu POLRI menjalin kerjasama dengan Kepolisian Filipina dan Thailand. Di samping dana dari Arab Saudi, sumber pendanaan teroris lainnya adalah dari hasil kejahatan merampok dan usaha menjual voucher telepon seluler yang keuntungannya mencapai Rp. 5 juta per hari. ${ }^{43}$

Menurut Majalah Tempo ${ }^{44}$, biaya operasi teroris berasal dari donatur asing dan lokal. Pada tanggal 12 Desember 2004 Muhammad Yusuf Faiz, Nasir, dan Deddy Resdiana yang berangkat ke Filipina untuk mendapat pelatihan militer, ditangkap di pelabuhan Zamboanga, Mindanao, Filipina Selatan. Dari tangan Faiz polisi menyita buku-buku tafsir dan uang sebesar US \$ 21 ribu. Menurut pengakuan Faiz dana tersebut diterima dari Abdullah Sonata, Ketua Komite Penanggulangan Krisis (KOMPAK). Uang tersebut diterima Sonata dari seorang Arab Saudi di sebuah restoran khas Timur Tengah di kawasan Jakarta Pusat. Uang yang diterima itu dalam mata uang Real yang kemudian ditukarkan Faiz dan Sonata ke dalam mata uang US \$. Rencananya dana tersebut akan diserahkan Faiz kepada Dulmatin untuk pembelian senjata. Sonata, yang ditangkap polisi akhir Juli 2005 di Rumah Sakit Harapan Kita, Jakarta, mengaku mendapatkan sumbangan dari sejumlah donatur untuk bantuan kemanusiaan di Ambon, Maluku. Sonata berperan sebagai kasir. Sumbangan tersebut sebagian digunakan untuk kegiatan operasional

\footnotetext{
${ }^{41}$ Kompas Cyber Media, 21 November 2005 (http://www.kompas.com)

${ }^{42}$ Tempo Interaktif, 21 Nopember 2005.

${ }^{43}$ Kompas Cyber Media, Op.Cit.

${ }^{44}$ Tempo, Majalah Berita Mingguan, No.40/XXXIV/28 November-4 Desember 2005. hal.
} 
KOMPAK, termasuk biaya sewa rumah kontrakan Ramli sebesar Rp. 300.000,tiap bulan. Ramli, yang sudah ditangkap polisi, bertugas membuat timer bom.

Masih menurut Majalah Tempo, dengan mengutip pernyataan Kapolri, Sutanto, dana-dana itu berasal dari jaringan teroris di luar negeri, lalu disalurkan oleh kasirnya ke sini. Sumber di Kepolisian RI, menyatakan bahwa hibah asing bukan hanya berasal dari Arab Saudi. Dalam pemeriksaan Dani Chandra, yang berperan sebagai kurir KOMPAK dari Solo ke Ambon, terungkap adanya bantuan dari Kuwait sebesar Rp. 750 juta pada akhir tahun 2001. Uang tersebut untuk pengungsi, pejuang Mujahidin, dan Laskar Jihad di Ambon yang dikirim ke Ambon melalui kantor pusat KOMPAK di Jakarta Pusat

Menurut Sidney Jones, Direktur ICG untuk Asia, seperti dikutip Majalah Tempo, selalu ada aliran dana setiap kali akan ada operasi pengemboman. Menjelang Bom Bali I, ada kucuran dana sebesar US \$ 35 ribu. Pada bom Marriot, masuk uang sebesar Rp. 76 juta. Untuk bom Kuningan mengalir dana sekitar Rp. 74 juta.

Untuk biaya operasional sehari-hari berasal dari infak anggota atau sumbangan perusahaan-perusahaan yang mendukung. Contohnya, sumbangan dari Joko Sumanto, pemilik Toko UD Masa di Wonoboyo, Wonogiri, Jawa Tengah sebesar Rp. 400 ribu yang diminta Sonata untuk para janda bom Bali I; Rp. 100 ribu per bulan yang diminta Sonata untuk mengurus istri Sawad (peracik bom Bali I) dan Musa alias Zulkifli Marzuki (Warga Negara Malaysia yang masih buron) di Megetan, Jawa Timur; Rp. 15 juta yang diserahkan kepada Faiz dan Usman untuk pembelian dua pucuk senjata, masing-masing seharga Rp. 6 juta, sesuai permintaan Faiz dan Usman untuk dipakai latihan jihad di Poso. Sisa uang tersebut untuk pengiriman kedua senjata itu.

Selain dari infak, kelompok teroris juga melakukan penggalangan dana lewat perampokan. Cara ini terungkap ketika polisi di wilayah Serang, Banten, meringkus Junaedi, Abdul Rauf, Andri Octavia, dan Audi Hidayat, dua tahun lalu. Imam Samudra memberikan mereka uang sebesar Rp. 6,5 juta, tiga pucuk senjata, dan sepeda motor, untuk merampok Toko Emas Elita Indah di Pasar Lama Serang pada bulan Agustus 2002. Mereka berhasil merampok 2,5 kg emas dan uang tunai sebesar Rp. 5 juta. Uang tersebut dipakai sebagai modal bom Bali I. ${ }^{45}$ 
Apakah kelompok teroris di Indonesia mendapatkan dukungan pendanaan dari jaringan fmansial Al Qaeda? Dari pemberitaan di media massa tidak ada penjelasan mengenai hal ini dari Otoritas di Indonesia. Bahkan, pihak Otoritas, yang nampaknya lebih suka menggunakan istilah "kelompok teroris", tidak menyebutkan kelompok teroris yang melakukan aksi-aksi bom di Indonesia sebagai bagian dari Jamaah Islamiyah (JI) ${ }^{46}$ sebagai "the South East Asian terrorist organisation based in Indonesia". ${ }^{4}$

Tetapi berbagai sumber menunjukkan adanya dukungan dana dari Al Qaeda. Dalam peledakan bom Bali I, menurut Yoram Schweitzer dan Sari Goldstein Ferber: ${ }^{48}$

The attack was paid for by funds that Khaled Sheikh, al-Qaeda 's liaison officer, transferred to Hambali, his friend and confidant, which Hambali transferred to Mukhlis, who was supervising the attack. The attack cost \$30,000, which accounted for a portion of a total sum of \$100,000 that al-Qaeda transferred to al-Jama'a alIslamiya via Khaled Sheikh, as an expression of satisfaction with the affiliate's activity in Southeast Asia. Part of the funding was acquired through a robbery carried out by a number of members of network.

Episode penyerangan di Bali ini, menurut Schweitzer dan Ferber, mengilustrasikan suatu hubungan dekat antara Al Qaeda dengan beberapa afiliasinya. Dalam peledakan di Hotel Marriot, Jakarta, pada bulan Agustus 2003:

The attack was commanded by two of the group's senior members who were also involved in the Bali attacks and had not been

${ }^{46}$ Pada tanggal 23 Oktober 2003 Amerika Serikat, pasca bom Bali I, menamakan JI sebagai "a Specially Designated Global Terrorist (SDGT) dan dimasukkan ke dalam daftar "a foreign terrorist organization." Dua hari kemudian, JI dimasukkan ke "the United Nations 1267 Committee's consolidated list of terrorist tied to Usama bin Laden (UBL). Al Qaeda or the Taliban." Ada 36 Negara yang mendukung dimasukkan JI ke dalam daftar tersebut.

47 ICG, Jemaah Islamiyah in South East Asia: Damaged but Still Dangerous, Executive Summary, Asia Report, 26 August 2003.

${ }^{48}$ Yoram Schweitzer, \& Ferber, Goldstein Sari, Op.Cit. hal. 66. 
apprehended, and was financed by the funds that Khaled Sheikh transferred to Hambali. ${ }^{49}$

Dalam kesaksian tertulis Jean-Charles Brisard di hadapan the Committee on Bank, Housing and Urban Affairs, United States Senate, tanggal 23 Oktober $2003^{50}$ dikatakan:

Direct funding was revealed, for example, by former Al-Qaeda 'representative in Southern Asia Omar al Faruq confessions to the US authorities regarding Al Haramain Foundation. Al Faruq stated that "Al Haramain was the funding mechanism of all operations in Indonesia. Money was laundered through the foundation by donors from the Middle East. He also stated that the charity was working under the control of a representative of Usama bin Laden.

Rohan Gunaratna, ${ }^{51}$ mengutip laporan agen-agen intelijen asing, mengungkapkan bahwa pada tahun 2000 Ayman al Zawahiri dan Muhammad Atef mengunjungi Maluku dan Irian Jaya guna mengkonfirmasikan preferensi Al Qaeda untuk "regrouping" di wilayah yang lemah penegakan hukumnya. Diungkapkan pula bahwa bom Natal tahun 2000 merupakan serangan yang dikoordinasi bersama Al Qaeda Manila dengan izin dari Malaysia dan Afganistan. Agen-agen intelijen Filipina dan Spanyol juga melaporkan keberadaan suatu tempat pelatihan (training camp) Al Qaeda di Indonesia. Kamp pelatihan Al Qaeda pertama di Indonesia tersebut berada di satu pulau yang belum teridentifikasi. Atas laporan tersebut, seperti ditulis Gunaratna, "...Jakarta's law enforcement authorities have yet to make any arrests despite intelligence from many sources that there are Indonesians serving with Hezbollah, JI, Al Qaeda, and other international terrorist groups." Otoritas Indonesia berada di bawah tekanan internasional yang intens ketika transkrip telpon dari sel Al Qaeda di Spanyol mengungkapkan pada bulan Nopember 2001 tentang keberadaan kamp pelatihan tersebut. Setelah melakukan investigasi berskala besar pihak keamanan kedua Negara tersebut mengidentifikasi suatu "hubungan antara jaringan Al Qaeda Spanyol dengan

\footnotetext{
${ }^{49}$ Ibid., hal. 70 .

${ }^{50}$ Jean-Charles Brisard, Op. Cit., hal. 18.

${ }^{51}$ Gunaratna, Op. Cit., hal. 199-200.
} 
aktivitas pelatihan militer di Poso, Sulawesi Tengah pada bulan Juli 2001." Laporan intelijen Indonesia yang dikutip Gunaratna mengungkapkan:

The training camp led by Omar Bandon consisted of 8-10 small villages located side by side on the beach, equipped with light weapons, explosives and firing range. Participants of the training are not only from local people but also from overseas. The instructur of the physical training in the camp is Parlindungan Siregar, a member ofAl Qaeda's network in Spain. ${ }^{52}$

Hal yang sama mengenai kamp pelatihan ini, disampaikan International Crisis Group (ICG) dalam ICG Asia Report, tanggal 3 Pebruari 2004, bertajuk "Indonesia Backgrounder: Jihad in Central Sulawesi". Berdasarkan sumbersumber intelijen Indonesia, dikatakan bahwa Parlindungan Siregar, orang Indonesia yang punya hubungan dengan sel Al Qaeda Spanyol, pergi ke Poso pada bulan Oktober 2000, waktu hampir bersamaan dengan pengiriman tim pertama dari Mujahidin KOMPAK. Penghubung lokal Siregar adalah seorang mujahid bernama Omar Bandon, nama lain, menurut sumber ICG di Poso, dari Mohammed Dong. Pada bulan Mei tahun 2001, menurut laporan intelijen tersebut, Siregar bersama pimpinan sel Spanyol Al Qaeda, Imad Eddris Barakat Yarkas, datang ke Poso. Hasil kunjungan tersebut, Yarkas menyetujui pengurusan pendanaan kamp pelatihan internasional tersebut. ${ }^{53}$ Dalam laporan ICG tersebut juga dinyatakan bahwa, "KOMPAK-Solo undertook to raise funds for both JI and Mujahidin KOMPAK. " 54

Menurut Yeo Wei Meng, seorang riset analist Program Terorisme dan Kekerasan Politik, Institute of Defense and Strategic Studies ${ }^{55}$,

Currently in Indonesia, it is estimated that 15-20\% of Islamic chanty funds are diverted to various politically motivated groups, and even some terrorist groups. For example, Laskar Jundullah has deceived

${ }^{52}$ Ibid.

53 ICG Asia Report N 74, "Indonesia Backgrounder: Jihad in Central Sulawesi, Jakarta/Brussels, 3 February 2004. hal. 12.

${ }^{54}$ Ibid., hal. 9.

${ }^{55}$ Yeo Wei Meng, Bali In The Shadow Of Terror, Asia Times online, October 13, 2004 (http ://www/atimes. com/atimes/Southeast_Asia/) 
funding from KOMPAK, the largest Islamic charity organization in Indonesia, as well as from the Al Haramian foundation, an international charity based in Saudi Arabia.

George Aditjondro, dalam wawancaranya dengan SBS Dateline, Australia's Special Broadcasting Services, mengemukakan pandangan yang lain, khususnya dalam menanggapi konflik di Poso, Sulawesi Tengah. Menurut Aditjondro, di setiap wilayah konflik di Indonesia, tentara yang menimbulkannya dengan mendanai dan mempersenjatai kedua belah pihak yang terlibat konflik. Dalam kasus di Sulawesi Tengah, pihak milisi Muslim dan Kristen.

So, the money do not have to come from rich people like Osama bin Laden and the weapons doesn't have to come from Southern Philippines or from other exotic places but it is actually coming from the official resources and that is why I am saying that the kind of terrorism which we see in Indonesia is home grown terrorism. It's a kind of duel function or tripple function of the armed forces. ${ }^{56}$

Pandangan Aditjondro ini bertentangan dengan pandangan A.M. Hendropriyono, mantan Kepala Badan Intelijen Negara (2001-2004), yang diungkapkan dalam wawancara dengan Majalah Tempo. Hendropriyono menyatakan, "..., Al Qaedah main di Poso, bukan Jamaah Islamiyah, bukan yang lain". ${ }^{7}$

Dari uraian tersebut di atas jelas ternyata bahwa aksi-aksi kelompok-kelompok terorisme di dalam negeri selama ini dimungkinkan terjadi karena adanya dukungan dana, baik dari dalam negeri maupun dari luar negeri, baik yang legal maupun yang ilegal. Maka, sejalan dengan strategi global pemberantasan terorisme, penghentian pendanaan terorisme memainkan peran sangat penting untuk menghentikan aksi-aksi terorisme yang telah merenggut begitu banyak korban selama ini di Indonesia.

\section{Upaya-Upaya Pemberatasan Pendanaan Terorisme}

56 SBS Dateline, Inside Indonesia's War on Terror, Former President of Indonesia Abdurrahman Wahid confirms involvement of the Indonesian Military Intelligence, SBS Dateline Archives, October 12, 2005.

${ }^{57}$ Majalah Tempo. Loc. Cit., hal. 46. 
Dengan mengkaji pendanaan terorisme, nampak jelas bahwa pendanaan terorisme merupakan suatu persoalan berwajah banyak (multifaceted problem) dan bersifat transnasional yang memerlukan respons kebijakan yang rumit baik pada level internasional, regional, maupun nasional. Pada dasarnya inti strategi pemberantasan pendanaan terorisme dilandaskan pada tiga pilar utama ${ }^{58}$, yakni, pendeteksian (detecting), pembongkaran (dismantling), dan penghalangan (deterring) jaringan pendanaan terorisme. Menurut Celina Realuyo ${ }^{59}$, pada pilar yang pertama dilakukan operasi-operasi intelijen dan penegakan hukum (law enforcement) untuk mengadili para pendana terorisme. Yang kedua, menggunakan tindakantindakan designasi publik dengan maksud menamai, mempermalukan, dan memblokir aset-aset kelompok-kelompok teroris dan para pendukungnya. Yang ketiga, dikembangkannya program-program pengembangan kapasitas untuk memperkuat aliansi negara-negara lain agar secara proaktif memerangi pendanaan teroris. Dua pilar yang pertama bersifat retrospektif, yakni melakukan investigasi pendanaan operasi yang diketahui setelah terjadi peristiwa/fakta. Pilar yang ketiga memusatkan perhatian pada peningkatan kapabilitas-kapabilitas negara-negara untuk menjaga sistem-sistem pendanaan internasional dari penggunaan yang salah oleh para pendana teroris.

Setelah tragedi 11/9 suatu komponen esensial strategi kontra terrorisme Pemerintah Amerika Serikat telah mengidentifikasi dan membongkar jaringan pendanaan organisasi-organisasi teroris. Upaya global menghentikan pendanaan terorisme secara fundamental merupakan suatu strategi preventif. Secara sederhana dapat dikatakan bahwa jika Amerika Serikat dengan dukungan komunitas global dapat menghalangi pentransferan dana-dana yang diperlukan untuk aksi teror, hal tefsebut dapat mencegah aksi-aksi terorisme berikutnya dan mencegah pembunuhan beribu-ribu manusia yang tidak berdosa. ${ }^{60}$

${ }^{58}$ Tiga pilar utama ini merupakan strategi Amerika Serikat dalam memerangi pendanaan terorisme (Lihat: Center for Defence Information, "Combating Terrorist Financing: A Key Aspect of the War on Terrorism", May 20, 2005) journals/ites)

59 Celina Realuyo, Building A Counterrorist Finance Regime, (http://usinfo.state.gov/

60 Jimmy Gurule, U.S. Expert Says International Alliances Against Terrorism Are Crucial, United States Embassy Tokyo, Japan (http://japan.usembassy.gov/) 


\section{Upaya-upaya Internasional dalam Pemberantasan Pendanaan Terorisme}

Pasca peristiwa 11/9 Pemerintah Amerika Serikat melakukan langkah penegakan hukum yang ditujukan kepada para pendana-pendana terorisme dengan Executive Order 13224 yang dikeluarkan oleh Presiden Amerika Serikat. Pemenntahan Presiden George W. Bush melakukan beberapa langkah untuk memberantas jaringan pendanaan terorisme. Executive Order (EO) 13224 memberikan kewenangan kepada Amerika Serikat untuk membekukan aset-aset milik badan-badan yang secara finansial mendukung organisasiorganisasi teroris yang teridentifikasi. Hasilnya, pada tahun 2003 aset-aset dari 321 badan dibekukan. Daftar Organisasi Teroris Asing (Foreign Terrorist Organization (FTO)) dari Depertemen Luar Negeri Amerika Serikat sangat penting untuk melakukan pembekuan tersebut, karena daftar itu memberikan dasar pengidentifikasian sumber-sumber pendanaan terorisme.

Penegak hukum dan agen-agen intelijen harus mengkoordinasikan upayaupaya untuk mendesignasi dan menginvestigasi para pemberi dana (financiers) dan memblokir aset-aset mereka. Strategi ini menuntut suatu kerja sama antara negara, antara lembaga, untuk melacak dana-dana terorisme dan mengamankan institusi-institusi finansial.

\section{Upaya Indonesia dalam Memerangi Pendanaan Terorisme}

Indonesia merupakan bagian dari masyarakat internasional dan menjadi salah satu Negara yang menjadi korban aksi terorisme. Memerangi pendanaan terorisme, sejatinya, merupakan salah satu strategi penting yang harus mendapatkan prioritas dalam upaya pemberantasan terorisme di Indonesia. Upaya memerangi pendanaan terorisme dilakukan melalui pendekatan integratif dengan upaya memerangi tindak pidana pencucian uang.

Dari aspek kebijakan legislasi mengenai terorisme, Pemerintah Indonesia telah melakukan upaya memerangi terorisme dengan ditetapkannya Undangundang Nomor 15 Tahun 2003 tentang Penetapan Peraturan Pemerintah Pengganti Undang-undang Nomor 1 Tahun 2002 tentang Pemberantasan Tindak Pidana Terorisme menjadi Undang-undang. Soal pendanaan terorisme dalam Undang-undang tersebut diatur dalam tiga pasal, yakni pasal II, ${ }^{61}$ Pasal

\footnotetext{
${ }^{61}$ Ketentuan Pasal 11 adalah sebagai berikut:
} 
$12,{ }^{62}$ Pasal 13 huruf a. Ketentuan-ketentuan ini berada di bawah BAB II tentang Tindak Pidana Terorisme. Sedangkan dalam BAB V mengenai Penyidikan, Penuntutan, dan Pemeriksaan di Sidang Pengadilan. Pasal 29 mengatur tentang pemblokiran harta kekayaan, Pasal 30 mengatur tentang kewenangan penyidik, penuntut umum, atau hakim untuk meminta keterangan dari bank dan lembaga jasa keuangan mengenai harta kekayaan setiap orang yang diketahui atau patut melakukan tindak pidana terorisme dan Pasal 35 ayat (5) mengatur tentang perampasan harta kekayaan yang telah disita dalam hal terdakwa meninggal dunia sebelum putusan dijatuhkan dan terdapat bukti yang

Dipidana penjara paling singkat 3 (tiga) tahun dan paling lama 15 (lima belas) tahun, setiap orangyang dengan sengaja menyediakan atau mengumpulkan dana dengan tujuan akan digunakan atau patut diketahuinya akan digunakan sebagian atau seluruhnya untuk melakukan tindak pidana terorisme sebagaimana dimaksud Pasal 6, Pasal 7, Pasal 8, Pasal 9, dan Pasal 10.

${ }^{62}$ Ketentuan Pasal 12 adalah sebagai berikut:

Dipidana karena melakukan tindak pidana terorisme dengan pidana penjara paling singkat 3 (tiga) tahun dan paling lama 15 (lima betas) tahun, setiap orang yang dengan sengaja menyediakan atau mengumpulkan harta kekayaan dengan tujuan akan digunakan atau patut diketahuinya akan digunakan sebagian atau seluruhnya untuk melakukan:

a. Tindakan secara melawan hukum menerima, memiliki, menggunakan, menyerahkan, mengubah, membuang bahan nuklir, senjata kimia, senjata biologis, radiologi, mikroorganisme, radioaktif atau komponennya yang mengakibatkan atau dapat mengakibatkan kematian atau luka berat atau menimbulkan kerusakan harta benda;

b. b. Mencuri atau merampas bahan nuklir, senjata kimia, senjata biologis, radiologi, mikroorganisme, radioaktif atau komponennya;

c. c. Penggelapan atau memperoleh secara tidak sah bahan nuklir, senjata kimia, senjata biologis, radiologi, mikroorganisme, radioaktif atau komponennya;

d. d. Meminta bahan nuklir, senjata kimia, senjata biologis, radiologi, mikroorganisme, radioaktif atau komponennya secara paksa atau ancaman kekerasan atau dengan segala bentuk intimidasi,

e. Mengancam:

1) Menggunakan bahan nuklir, senjata kimia, senjata biologis, radiologi, mikroorganisme, radioaktif atau komponennya untuk menimbulkan kematian atau luka berat atau kerusakan harta benda; atau

2) melakukan tindak pidana sebagaimana dimaksud dalam huruf b dengan tujuan untuk memaksa orang lain, organisasi internasional, atau negara lain untuk melakukan atau tidak melakukan sesuatu;

f. Mencoba melakukan tindak pidana sebagaimana dimaksud dalam huruf a, huruf b, atau huruf $c$; dan

g. Ikut serta dalam melakukan tindak pidana sebagaimana dimaksud dalam huruf a sampai dengan huruff. 
cukup kuat bahwa terdakwa telah melakukan tindak pidana terorisme. Di dalam ayat (6) Pasal tersebut ditetapkan perampasan oleh hakim tersebut pada ayat (5) tidak dapat dimohonkan upaya hukum. Yang dapat dilakukan, sebagaimana ditentukan dalam ayat (7) Pasal 35 adalah setiap orang yang berkepentingan dapat mengajukan keberatan kepada Pengadilan yang telah menjatuhkan penetapan sebagaimana dimaksud dalam ayat (5), dalam waktu 30 (tiga puluh) hari terhitung sejak tanggal pengumuman sebagaimana dimaksud ayat (3) Pasal ini.

Yang perlu dicermati adalah ketentuan dalam Pasal 29 yang menetapkan bahwa penyidik, penuntut umum, atau hakim berwenang memerintahkan kepada bank dan lembaga jasa keuangan untuk melakukan pemblokiran terhadap harta kekayaan setiap orang yang diketahui atau patut diduga merupakan hasil tindak pidana terorisme dan/atau tindak pidana yang berkaitan dengan terorisme.

Rumusan pasal ini akan menimbulkan pertanyaan, apakah penyidik, penuntut umum, atau hakim dapat menggunakan ketentuan ini sebagai dasar hukum untuk pemblokiran harta kekayaan setiap orang yang diketahui atau patut diduga digunakan untuk tujuan melakukan tindak pidana terorisme. Agaknya pembuat undang-undang, khususnya mengenai rumusan Pasal 29 ini, tidak memaharni bahwa isu utama pendanaan terorisme bukan hanya pada soal hasil tindak pidana terorisme berupa harta kekayaan, tetapi justru pada tujuan penggunaan harta kekayaan untuk melakukan terorisme. Hal ini harus dinyatakan secara tegas dan jelas, mengingat adanya harta kekayaan atau sumber pendanaan teroris yang diperoleh dari kegiatan usaha legal, tetapi digunakan untuk melakukan tindak pidana terorisme sebagaimana tercakup dalam perluasan rumusan kejahatan pencucian uang dalam Undang-undang No. 23 Tahun 2003 tentang Tindak Pidana Pencucian Uang ("UU TPPU") juncto Undang-undang No. 25 Tahun 2003 tentang Perubahan atas UU TPPU.

Undang-undang No. 15 Tahun 2003, menurut penilaian Ansyad Mbai Kepala Desk Anti Teror Menkopolhukam, masih lebih lunak dibandingkan dengan undang-undang sejenis yang dimiliki negara-negara tetangga seperti Filipina, Malaysia, Singapura dan Australia. Ini menyebabkan kurang efektifhya upaya kontraterorisme. Undang-undang ini lebih terfokus pada penanganan terorisme setelah kejadian aksi teror. Sementara yang penting dalam kontraterorisme adalah tindakan-tindakan preventif yang tidak cukup 
diatur dalam UU ini. Jadi, menurut Mbai UU Anti Terorisme penting untuk segeradirevisi. $^{63}$

Usulan perlu segera dilakukan revisi UU ini juga dikemukakan Muladi, Gubernur Lemhanas. Menurut Muladi, selain merevisi UU Anti Terorisme, perlu juga peningkatan kualitas Desk Anti Terorisme sebagai Badan Anti Teror yang bertindak tidak hanya melakukan pengkajian akar permasalahan, tetapi juga melakukan pencegahan yang lebih cepat serta menjalin kerja sama internasional. ${ }^{64}$ Soal revisi UU ini, Departemen Hukum, Perundang-undangan dan Hak Asasi Manusia, pada tahun 2004, telah melakukan pembahasan. Ada dua hal pokok yang diusulkan untuk direvisi, yakni, pertama, mengenai hukuman terhadap korporasi atau organisasi yang terlibat terorisme. Kedua, perpanjangan waktu penangkapan yang dapat dilakukan penyidik.

Menurut Muladi, usulan revisi UU yang dilakukan Depertemen Hukum, Perundang-undangan dan HAM masih jauh dari memadai. Harus ada revisi yang sesuai dengan standar internasional, namun tidak melanggar HAM. ${ }^{65}$ Sampai saat ini revisi atas UU No. 15 Tahun 2003 tersebut belum dilakukan.

Untuk melaksanakan UU ini, khususnya Pasal 33 dan 34, Pemerintah RI telah menerbitkan Peraturan Pemerintah RI No. 24 Tahun 2003 (PP No. 24 Tahun 2003) tentang Tata Cara Perlindungan terhadap Saksi Penyidik, Penuntut Umum, dan Hakim dalam Perkara Tindak Pidana Terorisme. PP No. 24 Tahun 2003 ini ditetapkan di Jakarta pada tanggal 14 Mei 2003.

Setahun sebelumnya, Presiden RI telah mengeluarkan dua Instruksi Presiden (Inpres) mengenai penanganan korupsi, masing-masing Inpres No. 4 Tahun 2002 yang ditujukan kepada Menteri Negara Koordinator Bidang Politik dan Keamanan sehubungan dengan terorisme dan Inpres No. 5 Tahun 2002 yang ditujukan kepada Kepala Badan Intelijen Negara sehubungan dengan terorisme.

Dari peraturan perundang-undangan anti terorisme yang ada saat ini, nampaknya masalah pendanaan terorisme sebagai faktor determinan penting dalam strategi pemberantasan terorisme, belum mendapatkan pengaturan yang memadai. Terkait dengan hal tersebut, Kapolri Jenderal Sutanto, Kepala BIN Syamsir Siregar dan Kepala Desk Anti Teror Ansyad Mbai, dalam rapat dengar

\footnotetext{
${ }^{63}$ KOMPAS, 21 Oktober 2005.

${ }^{64} \mathrm{http}: /$ www.kapanlagi.com

${ }^{65} \mathrm{Ibid}$.
} 
pendapat dengan Komisi I DPR RI di Gedung DPR Senayan Jakarta, meminta agar Dewan Perwakilan Rakyat segera meratifikasi Konvensi Internasional tentang Pemberantasan Pendananaan Terorisme (International Convention for the Suppression of the Financing of Terrorism, 1999). Sutanto menyatakan bahwa jika Konvensi ini diratifikasi, maka ada kewajiban untuk mencegah aliran dana dan mudah bagi penegak hukum untuk melacak aliran dana teroris. Data dari POLRI menunjukkan bahwa Dr. Azahari (sebelum ditembak mati) dan Noordin M Top berkali-kali mendapat bantuan dana dari luar negeri. Hal ini membuat mereka bebas bergerak dalam melakukan teror. ${ }^{66}$

Menurut Mbai ratifikasi Konvensi tersebut sangat mendesak dilakukan mengingat UU No. 15 Tahun 2003 tidak memadai sebagai perangkat hukum untuk mencegah terorisme di Indonesia. ${ }^{67}$ Ratifikasi Konvensi ini memang telah menjadi salah satu yang termasuk daftar RUU Program Legislasi Nasional (Proglenas) 2006 dari Badan Legislasi (Baleg) di DPR RI. Direncanakan pembahasannya dilakukan dalam masa sidang DPR RI pada tahun 2006 ini. Ratifikasi Konvensi ini tentu akan memperkuat rejim hukum nasional dan internasional dalam pemberantasan pendanaan terorisme. Konvensi ini memperluas kerangka hukum (legal framework) bagi kerja sama internasional dalam investigasi, penahanan, penuntutan, dan pengekstradisian orang-orang yang melakukan pendanaan terorisme. Hal ini dapat efektif berlaku jika didukung oleh hukum nasional dan prinsip-prinsip hukum nasional yang sejiwa dan senapas dengan Konvensi tersebut dalam kesadaran dan semangat untuk memberantas terorisme. Jika hukum nasional dengan segala perangkat penegakan hukum tidak siap atau tidak sesuai dengan ketentuanketentuan dalam Konvensi tersebut, maka Konvensi tersebut bisa tidak efektif ditegakkan.

Maka, Negara RI sebagai bagian dari masyarakat internasional yang samasama menjadi korban aksi terorisme seharusnya mempersiapkan sistem hukum nasional anti pendanaan terorisme yang sinergis dengan Konvensi ini. Dalam konteks itu, usulan Muladi untuk merevisi UU No. 15 Tahun 2003 sesuai dengan standar-standar Hukum Internasional menjadi relevan dan sangat penting. Hingga saat ini revisi UU No. 15 Tahun 2003 belum tuntas dibahas.

${ }^{66}$ Media Indonesia online, 9/2/2006.

${ }^{67}$ Ibid. 


\section{Penutup}

Dunia kini menghadapi perang baru. Perang global melawan terorisme. Suatu perang yang oleh Hakim Spanyol Baltazar Garzon disebut sebagai musuh bersama yang lebih rumit dan elusif daripada musuh-musuh yang dihadapi di masa lalu. Garzon, spesialist investagasi terorisme, kejahatan terhadap kemanusiaan, dan kejahatan internasional terorganisasi ini, menyebut kekuatan terorisme sebagai "new invisible power" yang dalam penggunaan kekuatannya itu tidak peduli akan jatuhnya korban-korban sipil tak berdosa. ${ }^{68}$

Fakta-fakta menunjukkan hal tersebut. Sejak Al Qaeda mengumumkan perang pada tahun 1998, telah terjadi 30 kali serangan teroris yang besar dan menelan banyak korban di Amerika Serikat, Inggris, Perancis, Spanyol, Pakistan, Kenya, Tanzania, India, Irak, Morrocco, Yemen, Tunisia, Indonesia, Arab Saudi, Turki dan Osetia Utara. Lebih dari 4.895 orang terbunuh dan 12.345 terluka. Hampir semua korban adalah orang-orang sipil tak berdosa.

Aksi terorisme model Al Qaeda ini akan terus berlanjut dan menjadi tantangan serius bagi negara-negara dunia, para intelijen, penegak hukum anti teroris dan lembaga-lembaga anti teroris dunia, baik untuk jangka pendek, jangka menengah dan jangka panjang. Hal ini ditunjukkan oleh fakta tidak ada tanda-tanda berakhirnya aksi terorisme tersebut. Semakin banyak para teroris yang terbunuh dan tertangkap, semakin banyak pula para sukarelawan yang direkrut dan menjadi teroris untuk menjalankan misi-misi terorisme. Kemampuan para teroris belajar dari keberhasilan dan kegagalan serangan memberikan keuntungan bagi mereka dalam meningkatkan pengetahuan, ketrampilan, teknologi, dan semangat inovasi serta resiliensinya.

Akhir perang jihad melawan tentara-tentara Uni Soviet di Afganistan pada akhir tahun 1980-an dan keberhasilan mengalahkan kekuatan super power pada masa itu telah memperkuat moral perang para mantan pejuang Afganistan (Afgan alumni) yang kemudian menyebar ke berbagai negara. Apa yang sedang terjadi di Irak saat ini kurang lebih menggambarkan situasi yang sama. Bukannya tidak mungkin dari Irak akan muncul para mantan Irak (Iraqi Alumni) seperti para teroris mantan Afganistan. Di Indonesia orang-orang yang menjadi tokoh-tokoh penting dalam jaringan terorisme yang melakukan aksi teror selama ini sebagian besar adalah alumni pejuang Afganistan. Jadi, dunia masih menghadapi perang global melawan terorisme.

\footnotetext{
${ }^{68}$ Radio Free Europe/Radio Liberty, 7 October 2005 (http:/www.rferl.org)
} 
Salah satu strategi penting dalam perang tersebut adalah memerangi dan memutuskan "the life blood of terrorist", yakni dana teroris. Dana/uang merupakan variabel konstan yang selalu ada dalam sejarah terorisme. Bahkan, eksistensi terorisme sangat bergantung kepada dana. Sekalipun dalam jumlah yang kecil. Tidak ada teroris, organisasi teroris yang melakukan pengorganisasian, pengrekruitan, perencanaan dan melakukan aksi tanpa dana. Karena menghentikan pendanaan terorisme merupakan kunci penting dan strategis dalam perang global melawan terorisme.

Negara-negara dunia telah menyadari dan telah pula melakukan berbagai upaya untuk membekukan, mengawasi, mengontrol pendanaan terorisme, baik melalui rezim hukum anti terorisme, maupun melalui rezim hukum anti pencucian uang. Upaya-upaya ini disertai dengan tindakan-tindakan legislasi, harmonisasi hukum nasional yang disesuaikan dengan standar hukum internasional, kerjasama antara lembaga penegak hukum, intilijen, lembaga anti pencucian uang, kerjasama bilateral, regional dan internasional.

Indonesia sebagai salah satu negara dari masyarakat dunia dan telah menjadi korban aksi terorisme telah pula secara proaktif ambil dalam upaya-upaya tersebut. Dari aspek rezim hukum anti pencucian uang Pemerintah telah mencatat kemajuan signifikan baik dari sisi legislasi, regulasi institusi keuangan, maupun dari sisi kelembagaan (institusi). Dengan demikian saat ini tidaklah mudah bagi para teroris menggunakan jaringan institusi finansial untuk mendanai aksi teroris di Indonesia.

Dari aspek rezim hukum anti terorisme, khususnya pendanaan teroris, Pemerintah Indonesia mencatat sejumlah kemajuan, teratama dengan meratifikasi International Convention for the Suppression of the Financing of Terrorism. Dengan ratifikasi tersebut, maka Pemerintah Indonesia memiliki landasan hukum yang kuat dalam melakukan langkah-langkah hukum memberantas pendanaan terorisme dengan negara-negara lain.

Tetapi kemajuan ini belumlah cukup. Sejumlah langkah masih harus perlu dilakukan Pemerintah Indonesia, di antaranya, merevisi UU anti terorisme yang harus memenuhi standar-standar hukum Internasional, pemberdayaan dan penguatan institusi-institusi penegak hukum di bidang terorisme, penegakan hukum di bidangbidang lainnya seperti keimigrasian, bea dan cukai, penertiban administrasi kependudukan, dan hal-hal lain terkait.

Upaya penting lainnya adalah pembangunan kesadaran masyarakat akan bahaya terorisme dan terus mendorong masyarakat untuk secara proaktif ambil bagian dalam memberantas kejahatan terorisme yang membahayakan masyarakat itu sendiri dan kehidupan berbangsa bernegara. Senada dengan itu Pemerintah Indonesia harus gigih membangun aspek kehidupan perekonomian masyarakat agar bebas dari 
kemiskinan dan ketidakadilan. Hal ini sangat penting sebab terorisme akan bertumbuh subur dalam suatu masyarakat yang dijerat kemiskinan dan ketidakadilan. Mewujudkan suatu masyarakat Indonesia yang adil, makmur dan sejahtera, merupakan salah satu strategi dan senjata ampuh melawan terorisme. 


\section{Daftar Pustaka}

\section{Buku}

Alldridge, Peter. Money Laundering Law: Forfeiture, Confiscation, Civil Recovery, Criminal Laundering and Taxation of the Proceeds of Crime, Hart Publishing, Oxford-Portland Oregon, 2003.

Atamasasmita, Romli. Pengantar Hukum Pidana Internasional, Cet. I. Bandung: Refika Aditama, 2000.

Badudu - Zain, Kamus Umum Bahasa Indonesia, Jakarta: Pustaka Sinar Harapan, 2001.

Gunaratna, Rohan, Inside Al-Qaeda, Global Network of Terror, London, UK: C.Hurst \& Co (Publisher) Ltd., 2002.

Hamzah, Andi. Asas-asasHukum Pidana, Cet. I. Jakarta: Rineka Cipta, 1991.

Jacqard, Roland, In the Name of Osama bin Laden: Global Terror and the Bin Laden Brotherhood, London and Durham: Duke University Press, 2002.

Jawahir, Thontowi. Hukum Internasional di Indonesia: Dinamika dan Implementasinya di Indonesia, Cet. I. Yogyakarta: Madyan Press, 2002.

Krieken, Van, Editor, Terrorismm and the International Legal Order, T.M.C. Asser Press, The Hague, 2002.

Nainggolan, Poltak Partogi. Terorisme dan Tata Dunia Baru, Cet. I. Jakarta: Pusat Pengkajian dan Pelayanan Informasi Sekretariat Jenderal Dewan Perwakilan Rakyat Republik Indonesia, 2002.

Todd, Paul \& Bloch, Jonathan, Global Intelligence - The World's Secret Services Today, London: Zed Books Ltd, 2003.

Yudhoyono, Susilo Bambang. 2002, Selamatkan Negeri Kita dari Terorisme, Cet. I. Jakarta: Kementerian Koordinator Polkam, 2002.

\section{Peraturan Perundang-Undangan}

Undang-Undang Dasar 1945 
Undang-Undang RI No.62 Tahun 1958 yo. UU RI No.12 Tahun 2006, tentang Kewarganegaran Republik Indonesia.

Undang-Undang RI No.8 Tahun 1981 tentang Kitab Undang-Undang Hukum Acara Pidana.

Undnag-Undang RI No.15 Tahun 2002 yo. UU RI No.25 Tahun 2003 yo. UU RI No.8 Tahun 2010 tentang Tindak Pidana Pencucian Uang.

Undang-Undang RI No.9 Tahun 1992 tentang Keimigrasian.

Undang-Undang RI No.37 Tahun 1992 tentang Hubungan Internasional.

Undang-Undang RI No.15 Tahun 2003 tentang Penetapan Perpu No.1 Tahun 2002 tentang Pemberantasan Tindak Pidana Terorisme menjadi Undang-Undang.

Undang-Undang RI No.24 Tahun 2000 tentang Perjanjian Internasional.

Keppres No.82 Tahun 2003 tentang Tata cara Pelaksanaan Pusat Pelaporan dan Analisis Transaksi Keuangan.

PP RI No.57 Tahun 2003, tentang Tata Cara Perlindungan Khusus bagi Pelapor dan Saksi Tindak Pidana Pencucian Uang.

Keppres No.1 Tahun 2004 tentang Komite Koordinasi Nasional Pencegahan dan Pemberantasan Tindak Pidana Pencucian Uang.

Vienna Convention on Diplomatic Relations and Optional Protocols 1961. 